\title{
Serodiscordant twins: A case report of vertical HIV transmission during PMTCT option B+ role out
}

\author{
Carien Lion-Cachet* \\ Sub-District Family Physician, North West Department of Health, South Africa
}

\begin{abstract}
Similar factors promote vertical transmission of HIV in singleton pregnancies as in twin pregnancies. MTCT (mother to child transmission) in single pregnancies are associated with viral, maternal, obstetrical, foetal and infant factors. In twin pregnancies factors associated with serodiscordance are not clear. Mechanisms implicated are uterine contractions, mixing mother and foetal blood ( $2^{\text {nd }}$ twin), broken skin, exposure in the birth canal ( $1^{\text {st }}$ twin). Since Antiretroviral Therapy as Prevention of MTCT (ART PMTCT) the most important factor associated with vertical HIV transmission is the Viral Load (VL). Due to early attainments of NSP goals of $2 \% 6$ weeks and 5\% 18 months HIV rates Elimination of MTCT (EMTCT) became a possibility. New challenges en route to eliminate HIV are interventions to reverse HIV latency and to induce an effective anti-HIV immune response. Twin studies could be utilised to improve the understanding of the role of host genetics, co-infections and HIV sub-types in HIV transmission.
\end{abstract}

\section{Introduction}

We describe a case of discordant dizygotic (DZ) HIV-exposed twins. This is a recording of Prevention of Mother to Child Transmission (PMTCT) and Early Infant Diagnosis (EID) and their unrivalled success in HIV management. Each pregnant mother needs to be told that her adherence to Antiretroviral Therapy (ART) and her neonate's PEP (Post-exposure Prophylaxis) offer them a portal to the future.

It has been shown that in South Africa (SA) one out of three females of childbearing age are Human Immunodeficiency Virus (HIV) infected [1]. Initial unequivocal evidence came to light that to introduce antiretroviral therapy (ART) at CD4 levels of $350-500$ cells $\times 109 / \mathrm{L}$ in all adults, including pregnant women is beneficial for mortality and morbidity outcomes [2,3]. It follows naturally that the earlier the initiation of ART takes place in pregnancy, the lower is the risk of HIV transmission to the infant. Due to earlier ART initiation the proportion of pregnant women living with HIV in South Africa on ART increased from $83 \%$ in 2009 to $87 \%$ in 2012 [4]. The United Nations Acquired Immune Deficiency Syndrome (UNAIDS) global report stated in 2012 that without any interventions, between 15 and $45 \%$ of infants born to HIV infected mothers could acquire the disease during pregnancy, birth and breastfeeding. It is suggested that $10 \%$ of neonates who have HIV infection contract it in utero, $60 \%$ are infected peri- or intra-partum, while $30 \%$ of infants acquire HIV postnatally $[5,6]$.

In December 2014 the newly published SA Clinical HIV Guidelines [5] recommended that all HIV positive pregnant women should be counselled and initiated on lifelong ART on the day of the pregnancy and HIV- diagnosis, regardless of the CD4 level. The universal test and treat option was thus incorporated for the first time into the PMTCT program in pregnant women in 2014 [6].

The so-called B+ programmatic option of PMTCT was effected on 1 January 2015. In practice it relied on

- Identification of maternal seroconversion as a priority
- Initiation of ART in newly infected women in pregnancy, during breastfeeding and one year after pregnancy.

- $\quad$ Provision of appropriate prophylaxis or CART (combination ART) to HIV-exposed infants

\section{Maternal seroconversion}

During maternal seroconversion, the viral load (VL) is usually at its highest level and therefore also the risk of HIV transmission from the mother to her child. As a consequence the monitoring of both HIV positive and negative women in pregnancy has been prioritised. HIV negative pregnant women are tested 3 monthly for seroconversion. New to the December 2014 guidelines is the recommendation that HIV positive pregnant women already on ART should have a VL done as soon as possible after the first menstrual period is skipped. Needless to say that PMTCT relies on a first antenatal care (ANC) visit as soon as pregnancy is diagnosed [6]. If the VL in ART experienced women is not less than 1000 copies $/ \mathrm{mL}$, intensified adherence counselling is necessary. The VL is repeated after 1 month. If the VL is equal or less than $1 \log$ drop, the expectant mother is changed to the second line regimen [6,7]. This is because it was shown by trials like HPTN052 [8] that ART prevented HIV transmission in discordant couples, which promoted the test and treat approach in pregnant women to prevent vertical transmission [7].

Correspondence to: Carien Lion-Cachet, Sub-District Family Physician, North West Department of Health, Tlokwe /Potchefstroom, South Africa, Tel: 0833957376, E-mail: carienlc@koshcom.co.za

Key words: vertical HIV transmission, singleton, twins, serodiscordance, concordance, MTCT, PMTCT, EMTCT

Received: November 28, 2016; Accepted: December 22, 2016; Published: December 26, 2016 


\section{Early infant diagnosis}

Besides PMTCT, early infant diagnosis (EID) is introduced to improve outcomes in paediatric HIV [8]. In infants $<2$ months of age coverage of HIV diagnosis reached $72,6 \%$ in January 2012 [4]. The EID programme is aimed at improving the proportion of infants diagnosed. Doing polymerase chain reaction (PCR) blood tests on postnatal samples aids the early identification of transmitted HIV [8]. A positive PCR on cord blood indicates in utero infection. A negative cord blood sample followed by a positive PCR test, 4-26 weeks after birth is indicative of perinatal HIV transmission. If a PCR sampled more than 4 weeks after birth is negative and followed by a positive PCR the infant is considered to have acquired infection around the midpoint of the test interval starting at birth [8-11]. It was shown previously that $96 \%$ of perinatally infected infants will have a positive PCR Deoxyribonucleic Acid (DNA) test by 4 weeks of age [12]. Every HIV exposed infant currently receives a DNA PCR at birth to ensure that the appropriate infant prophylaxis or cART is continued from in utero to the peri-partum period. This decision was implemented in June 2015 by the National HIV Paediatric testing guidelines $[8,9]$.

\section{Prophylaxis or cART indicated in HIV exposed infants}

Every HIV-exposed neonate, not only high risk neonates, gets a birth PCR. It is essential for in utero infected neonates to be diagnosed promptly. It should be taken into account that CART might contribute to a false negative PCR test [13-15]. If the PCR test is positive the infant is regarded as HIV positive and should be 'fast-tracked' into the HIV treatment programme within seven days [16]. Besides initiation of ART, HIV paediatric outcomes were also improved by CoTrimoxazole prophylaxis. This is usually given after the first 6 weeks of life at completion of Nevirapine prophylaxis or with cART during the first year of life. It is unnecessary to wait for the second confirmative positive PCR result before initiation. An HIV-exposed infant under 18 months may not be regarded HIV negative until the PCR is repeated 4 weeks after completion of Nevirapine prophylaxis and 4 weeks after breastfeeding stops $[4,15]$. Sero-reversion in absence of Nevirapine prophylaxis and the cART from the mother's breast milk may take up to 4 weeks. At the age of 18 months the rapid HIV test which is antibody based is conclusive, as the mother's antibodies will no longer persist in the child's body. A positive rapid test implies that the child is forming his own antibodies campared to a negative test that confirms that the child has not been HIV-infected. The median survival time of infected infants without any interventions, is one year. As many as $50 \%$ of vertically infected children will die by two years without ART. Because the morbidity and mortality is even higher in HIV infected infants than adults, every possible effort should be undertaken to adhere to PMTCT $[4,15]$.

Risk of HIV transmission from mother to child in multiple pregnancies has not been studied as extensively as Mother To Child Transmission (MTCT) in singletons. It is a well-known fact that twin pregnancies are associated with an increased risk of premature labour (PREM) and premature rupture of membranes (PROM). Similarly both PREM and PROM are risk factors for MTCT [16]. It is however not necessarily true for twin pregnancy to be associated with MTCT more often than singletons. There is a paucity of literature on the risk of MTCT in twins and serodiscordance between second and first born twins [16,17].

The exact mechanism of intrapartum vertical HIV transmission remains unclear even in 2016. A number of hypotheses, some of which are contradictory, have been formulated for a plausible explanation of discordance in HIV infected twins.

- During contractions maternal and foetal blood may be mixing. This makes the second twin the higher risk candidate, because she/he is in the uterus for longer duration [16].

- Broken skin may become contaminated with infected maternal blood or vaginal secretions [16].

- The infant might be infected through the mucosa by swallowing infected maternal secretions or bloods, while moving through the birth canal. Genital shedding of the HIV virus is higher during pregnancy than in non- pregnant females. First born twins have greater exposure to mucus and blood during a vaginal delivery. Second born twins spend a comparatively shorter time in the birth canal than the first born baby. The latter baby had already dilated the passage and mechanically removed most of the infected material [17-19].

- The overall transmission rate of HIV was significantly lower for caesarian sections than vaginally delivered twins in both first and second born babies. Relatively fewer second born twins were HIV infected in utero during caesarian sections than vaginally delivered second born twins. Twins and singletons alike had a low risk of MTCT when the mother received PMTCT ART with an undetectable VL. Consistent findings for most twin studies after 2007 were the close association between unfavorable WHO stage, detecteble VL and increased HIV transmission in utero, intra/peri-and postpartum [16].

Discordance in twins is influenced by the same factors as HIV transmission in singleton pregnancies. The risk factors for singleton MTCT are organised into viral, maternal, obstetrical, foetal and infant clusters (Table 1) [13]. It is quite evident though that there must be additional factors involved in twins becoming HIV discordant.

As early as 1986 a case of transmission of HIV to only one member of a DZ twin pair was written up. Suggestions were put forward of different susceptibilities due to either inherent resistance or lack of unfavourable host factors for the HIV virus. One possible reason for the theory of a host co-factor is that HIV transmission rate is higher where the genital mucosa is affected by a concomitant STI like Herpes Simplex virus. This case report concluded that there was no development of opportunistic infections in both the HIV - infected parents and infant, because only a fraction of patients with AIDS related complex progressed to full blown AIDS [20-23].

The risk factors for postpartum transmission are in essence associated with maternal factors unsuppressed VL during and after pregnancy, seroconversion during breastfeeding and infant factors like the immature immune system and gastrointestinal system in mixed feeding before six months of age. Postnatal seroconversion seems not to be influenced by twinning per se [20].

In the era of EMTCT (Elimination of Mother to Child Transmission) birth order and mode of delivery in twins are no longer regarded as important risk factors for HIV transmission in twins [16]. In 2010 a new challenge was posed by HIV transmission from a mother to one male baby in a pair of DZ twins despite adequate PMTCT prophylaxis. HLA is situated on mucosal cells in the host. These epitopes bind with viral peptides and then present antigens to the CD 8 T-cells and CD4 T-cells. The CD-8 cells are known as cytotoxic T lymphocytes (CTL) and exert immune pressure on HIV-1. CTL lymphocytes and Thelper cells are present in all neonates at birth. HIV specific CTL responses in HIV exposed but uninfected neonates seem to be more efficient due to the way HLA haplotypes bind and present HIV 1 epitopes [24-27]. 
Table 1. Factors affecting MTCT of HIV-1 in Twins intra and peripartum (A summary of relevant literature).

\begin{tabular}{|c|c|c|c|c|c|}
\hline Reference & Year & Hypothesis & Findings & Study Type & Discussion \\
\hline$[16]$ & 1995 & $\begin{array}{l}\text { Assessing data in International } \\
\text { Registry of HIV-exposed twins } \\
\text { to identify and understand co- } \\
\text { variates and mechanisms of } \\
\text { MTCT.16 }\end{array}$ & $\begin{array}{l}\text { HIV transmission of second twins } \\
\text { occurs in utero, versus firstborns } \\
\text { are mostly intrapartum. HIV } \\
\text { infected. To reduce exposure to } \\
\text { HIV in the birth canal may reduce } \\
\text { MTCT.16 }\end{array}$ & $\begin{array}{l}\text { Prospective sampled twins. } \\
\text { ART status unknown } \\
\text { zygocity undetermined }\end{array}$ & $\begin{array}{l}\text { Other authors } 13 \text { found birth order and delivery route } \\
\text { posed no risk for MTCT of HIV in any member of a } \\
\text { twin pair. Intrapartum transmission of HIV in twins not } \\
\text { regarded as major risk factor in this study. }\end{array}$ \\
\hline$[17]$ & 2003 & $\begin{array}{l}\text { Risk of birth order and route of } \\
\text { delivery for MTCT of HIV1 in } \\
315 \text { twins. Malawi 1994-1998.17 }\end{array}$ & $\begin{array}{l}\text { First and second born have twins } \\
\text { have equal risks for MTCT HIV } \\
\text { infection. Caesarean Section } \\
\text { found to have a } 50 \% \text { lower risk } \\
\text { for MTCT. }\end{array}$ & $\begin{array}{l}\text { Restrospectiv e sampling. } \\
\text { Prospective observation from } \\
\text { birth. Done in pre- ART era. }\end{array}$ & $\begin{array}{l}\text { More in utero/perinatal HIV infections in twins are } \\
\text { concordant as due to chance. One twin classified } \\
\text { discordant post in utero MTCT. High maternal VL } \\
\text { found to be consistently related to HIV MTCT and thus } \\
\text { concordance in twins.. PCR on cord blood and } \geq 4 \text { weeks, } \\
\text { categorised infection as peri or postpartum. } 18 \text { Selective } \\
\text { HIV transmission may be proof of intrinsic factors in } \\
\text { virus more causal than host genetics. } 19\end{array}$ \\
\hline [19] & 1991 & \begin{tabular}{|l|} 
Study of twins and siblings \\
to determine the biological \\
background on perinatal HIV \\
transmission and clinical outcome \\
of infection. To obtain data for \\
counselling HIV positive mothers \\
planning further pregnancies.19
\end{tabular} & $\begin{array}{l}\text { Twins and second born infants of } \\
\text { HIV positive women are not at } \\
\text { increased risk of MTCT. }\end{array}$ & Multicentre prospective trial & $\begin{array}{l}\text { Factors not increasing HIV transmission risk: PREM } \\
\text { and twin deliveries. Concordance shown in relation to } \\
\text { zygosity in perinatally infected twins: The RR of HIV in } \\
1 \text { twin when the other had HIV: } 23-1(95 \% \text { CI } 3-3 \text { to } 162- \\
1 ; p<0-00001) \text { Referral to other reports of serodiscordant } \\
\text { HIV- infection: } 1 \text { in mono and } 2 \text { in dizygotic twins. } 20,21\end{array}$ \\
\hline [22] & 1986 & $\begin{array}{l}\text { Case report with Title: } \\
\text { "Transmission of Human } \\
\text { Immunodeficiency Virus from } \\
\text { Parents to Only One Dizygotic } \\
\text { Twin." } 22\end{array}$ & $\begin{array}{l}\text { Could HIV transmision in utero } \\
\text { to one DZ male twin be due to } \\
\text { different degrees of exposure } \\
\text { to maternal blood or birth } \\
\text { canal secretions? Could the } \\
\text { neonates have a different HIV } \\
\text { susceptibility?22 }\end{array}$ & $\begin{array}{l}\text { Dizygotic male twins and } \\
\text { first born neonate with } \\
\text { weight of } 2,3 \mathrm{~kg} \text {, non-breast } \\
\text { feeding. }\end{array}$ & $\begin{array}{l}\text { Reported early in AIDS pandemic: Some of the findings } \\
\text { i.e. early gestational transplacental transmission causes } \\
\text { late expression of the disease are no longer applicable. } \\
\text { Because highly sensitive PCR HIV TNA/vs PCR HIV } \\
\text { DNA EID is possible even at birth. In } 1986 \text { antibody } \\
\text { based tests were used to diagnose HIV. Because of } \\
\text { transfer of maternal antibodies to the neonate in utero } \\
\text { a positive HIV test only proved HIV exposure not } \\
\text { infection. The rapid test currently used to finally rule out } \\
\text { HIV is valid after the age of } 18 \text { months in children. }\end{array}$ \\
\hline [23] & 1997 & $\begin{array}{l}\text { "Vertical transmission of human } \\
\text { immunodeficiency virus type } 1 \text { : } \\
\text { insights from studies of multiple } \\
\text { pregnancies." The rationale } \\
\text { is that twins share an in utero } \\
\text { environment and thus have } \\
\text { duplication of at least } 50 \% \text { of } \\
\text { genetic material } 23\end{array}$ & $\begin{array}{l}\text { Insight was gained in } \\
\text { epidemiology and natural history } \\
\text { of HIV. Summary of } 3 \text { projects } \\
\text { e.g.HIV transmission and AIDS } \\
\text { free survival in The International } \\
\text { Registry of HIV - Exposed Twins, } \\
\text { etc. }\end{array}$ & $\begin{array}{l}\text { Retrospective observational } \\
\text { quantative. }\end{array}$ & $\begin{array}{l}\text { HIV-1 transmission was noted in this study to have an } \\
\text { increased frequency in first born MZ twins during labor } \\
\text { and delivery, and immunogenetics might not have an } \\
\text { effect on susceptibility for the virus. }\end{array}$ \\
\hline [24] & 2007 & $\begin{array}{l}\text { Twin pregnancy as a risk factor } \\
\text { for mother to child transmission } \\
\text { of HIV1: trends over } 20 \text { years } 24\end{array}$ & $\begin{array}{l}\text { Aim of study was to assess } \\
\text { whether twin pregnancies are } \\
\text { at increased risk of MTCT } \\
\text { HIV transmission compared } \\
\text { to singletons (Three eras were } \\
\text { used in the study i.e. pre- ART } \\
\text { prevention, zidovidune mono } \\
\text { therapy in pregnancy and the } \\
\text { HAART era from 1997.) }\end{array}$ & $\begin{array}{l}\text { Prospective observational } \\
\text { study, quantitative. }\end{array}$ & $\begin{array}{l}\text { The authors found that MTCT rate in twins was indeed } \\
\text { higher in twin pregnancies the singletons. This difference } \\
\text { between twins and single pregnancies only normalised } \\
\text { with the introduction of ART. This was a statistically } \\
\text { significant finding. PREM before } 33 \text { weeks was fourfold } \\
\text { in twins that in singletons. Statistically non- significant } \\
\text { trends were higher emergency Ceasarean Section and } \\
\text { PROM rates in twins than singletons. No difference } \\
\text { between birth maternal VL or ART regimen between } \\
\text { twins singletons.Findings in contrast to Italian study } \\
1980.19\end{array}$ \\
\hline [25] & 2010 & $\begin{array}{l}\text { A case of DZ twins discordant for } \\
\text { HIV-1 despite PMTCT25 }\end{array}$ & $\begin{array}{l}\text { Issue here is whether human } \\
\text { leukocyte antigen (HLA) } \\
\text { homozygosity disadvantaged the } \\
\text { HIV infected DZ twin }\end{array}$ & Case Report & $\begin{array}{l}\text { Heterogozygocity for class } 1 \text { and } 11 \text { alleles might have } \\
\text { protected the other DZ twin against HIV infection. } 25\end{array}$ \\
\hline [27] & 2006 & $\begin{array}{l}\text { "Higher In Utero and Perinatal } \\
\text { HIV Infection Risk in Girls Than } \\
\text { Boys"27 }\end{array}$ & $\begin{array}{l}\text { Girls were at higher risk(in utero } \\
\text { and perinatal HIV than boys }\end{array}$ & $\begin{array}{l}\text { Re-analysis of } \\
\text { prospective } \\
\text { trial. Pre ART17,18 }\end{array}$ & $\begin{array}{l}\text { The authors reported that parallel with the HLA } \\
\text { hypothesis, h compatibility between maternal } \\
\text { lymphocytes and antigens derived from infant Y } \\
\text { chromosome reduce the risk of HIV transmission in male } \\
\text { infants }\end{array}$ \\
\hline [28] & 2011 & $\begin{array}{l}\text { "HIV-1 infected monozygotic } \\
\text { twins: a tale of two outcomes" } 28\end{array}$ & $\begin{array}{l}\text { Aim: To investigate HIV-1 } \\
\text { evolution in MZ twins infected } \\
\text { simultaneously at birth with } \\
\text { HIV-1 after a blood transfusion. } \\
\text { Transfused blood to both was } \\
\text { donated by a single source. }\end{array}$ & Case Report & $\begin{array}{l}\text { Evolutionary processes and the dynamics in the viral } \\
\text { population shaped the eventual viral diversity in two } \\
\text { monozygotic twins. Growth rate, recombination and } \\
\text { selection pressure all played a role in the evolutionary } \\
\text { outcome. Despite being identical replicas at transmission } \\
\text { early infection dynamics was impacted upon by random } \\
\text { epigenetic. Understanding of the influence of host- } \\
\text { virus interactions in HIV infestation is still not fully } \\
\text { understood. }\end{array}$ \\
\hline
\end{tabular}

CI: Confidence Interval, RR: Relative Risk 
The term "slow progressors" is used in those HIV infected individuals where the immune system deteriorates at a much slower rate than expected. More recently a group has been identified whose VL never increase. This group is known as "elite controllers" of the HIV organism. Around the world several landmark studies are ongoing to provide explanations to questions of why some HIV infected people produce neutralising antibodies against HIV, and others do not. The virus has the ability to replicate exponentially producing up to 1010 copies daily. The virus is error prone and also due to the rapid multiplication process mutated viruses develo. Some mutations are present after only one change in amino acid base sequence i.e., K103N mutation in EFV/NNRTI resistance. In addition the HIV envelope cloaks itself with sugars of glycans which prevents human antibodies to attack its vulnerable sites. Structural biologists have recently been able to manufacture a protein similar to that found in the trimeric viral envelope. The hope is that these will elicit a broad neutralising antibody response in humans. Clues to the phenomenon of differing susceptibilities to HIV between individuals could path the way to finding a cure for HIV [28-30].

\section{Case report}

At presentation to a primary health care (PHC) facility in Dr Kenneth Kaunda District, North West Province of SA, Mrs. C.M. was found to be a pregnant for the third time. She had two previous normal vaginal deliveries. Her date of birth was 13 March 1979, which made her nearly 35 years old. During her first antenatal visit on 28 January 2014 she was diagnosed with HIV. According to the first day of her last normal menses, the gestational age of her pregnancy was assessed to be 16 weeks. On this first visit she was initiated on the antiretroviral regimen as stipulated by the revised SA PMTCT Guidelines of March 2013.She was initiated on Tenofovir, Lamivudine and Efavirenz, as a fixed triple drug combination in addition to her routine antenatal supplements. Her CD4 count at the time was 817 cells x 109/L. The first antenatal sonar done at 28 weeks indicated that she was expecting twins. Twin pregnancy is regarded as a high risk pregnancy according to Basic Antenatal Care (BANC). From the patient records it appears as if she attended the high risk antenatal clinic for the remainder of her pregnancy. A boy and a girl were delivered by caesarian section on the $26^{\text {th }}$ of June 2014 at 35 weeks gestational age. Of this DZ set of twins, the male was the first born. His weight at birth was $2,4 \mathrm{~kg}$ while his sister weighed $2,3 \mathrm{~kg}$. Both the babies received their first dose of Nevirapine immediately after birth in the operating theatre according to the Postexposure Prophylaxis (PEP) guidelines for neonates.

Although the mother returned to the high risk obstetric clinic for the rest of her antenatal care visits, it is not clear whether she actually received $\mathrm{ART}$ at the end of these visits. The re assessment of the VL was documented after she returned to the referring PHC clinic on 2 September 2014. The VL was not suppressed as it was $28957 \mathrm{cps} / \mathrm{mL}$ after receiving ART for about 8 months. The VL of the mother was neither assessed at delivery nor after three months treatment. No documentation could be found whether she continued with ART during and after pregnancy. No prescription for ART to take home could be found in the hospital file. Another possibility was that each facility accepted that her HIV management was the responsibility of the opposite one. The mother breastfeed the twins since their birth, but it was not noted if it was exclusive breastfeeding.

As Mrs C.M. had been initiated on ART five months previously, no Polymerase Chain Reaction (PCR) tests were indicated to be done on the babies at birth. According to the Clinical HIV Guidelines of
November 2014, neonates born to HIV infected mothers on lifelong ART were to receive Nevirapine prophylaxis for 6 weeks, because the mother's VL was expected to be non-detectable. It was documented that the mother collected Nevirapine for both twins in their Road to Health Booklets.

Both parents attended the first postnatal visit on the third day of life at the PHC clinic of origin. The twins were then registered on the Extended Program for Immunisation (EPI) at this clinic. No PCR was performed on either baby nor was any management plan discussed with the parents. On their return for the 6 weeks EPI visit on 08 Aug 2014 the male baby tested PCR negative, but his sister was HIV PCR positive. This was confirmed by a second PCR test which led to referral to the Wellness clinic at the hospital for initiation of ART. It was more practical for the mother to attend the PHC clinic adjacent to the Wellness clinic. For an unknown reason the twins continued on EPI at the initial clinic. A second VL evaluation on Mrs C.M. on 9 Dec 2014, was $13950 \mathrm{cps} / \mathrm{mL}$. The female baby had a VL of 321000 copies $/ \mathrm{mL}$ on the same date. It also became clear that the infected female baby had never been initiated on ART, because the father prohibited the motherbaby pair to take any ART. According to Mrs C.M. her husband did not trust the diagnosis of HIV as it was diagnosed in just one of the twins. The challenge was now to motivate the mother to keep to her follow-up appointments. The home visits by the community health workers and the clinician were mostly unsuccessful parents were seen together only on one occasion by the community health care workers and program manager of the clinic. The mother did not live with the father of the twins and had an alternative address on the farm besides that of the house nearby the clinic. She was living in the backyard of her aunt's property. The mobile clinic was alerted to be on the lookout for the patient. The mother appeared reticent to start the infected twin on ART and blamed the father of the children for her mistrust. She even acknowledged that she was prevented to obtain ART for herself and the infected infant. The social worker was contacted and after some deliberation she was intsrumental in completion of a supervision order. Although this could shatter the little trust that mother had in the public health system, the clinicians were compelled by law to report a case of neglect to judiciary system with the aid of the social worker. She had the task to supervise the babies' care and if necessary arrange placement in a safe centre. Social services rely on the help of the South African Police (SAP) to ensure that the infants received this essential medical care.

Mrs CM had repeated, thorough counselling at a number of clinic visits conducted by the family physician, medical officer, professional nurses and community health workers from September 2014 to January 2015. It seemed as if she lacked family support as she attended the clinic usually on her own with the twins. The mother eventually only managed to collect ART for her daughter for the first time in January 2015. It was soon apparent that the Lopinavir/ritonavir, Lamivudine and Abacavir regimen was not collected according to the monthly schedule. In September 2015 the viral load of the little girl was 311000 copies/mL and in February 2016 it became undetectable. On the weight for height growth chart the weight curve faltered and crossed percentile lines since November 2015. On 17 February 2016 she was referred to the paediatric department of the second level hospital for severe malnutrition as she was oedematous at that visit. No records existed at the hospital that the child was ever admitted to the hospital. At the end of April 2016 Mrs C.M. reported that her daughter died on 23 March 2016.

In June $2016 \mathrm{Mrs}$ CM was referred to the second clinic for her own 
ART, yet once more and again on her request. There was no referral letter from the referring clinic filed in Mrs CM records at the new clinic. Here she was classified as being ART naive based on her own report! As her CD4 count was $664 \times 109$ cells/L and Universal Test and Treat guideline only became official in September 2016, she was considered not to be eligible for ART at the time! She elected not to divulge that she had been initiated in 2014 on lifelong ART for EMTCT while pregnant.

The mother was once more traced by the community health workers and the mobile clinic. The health care team at the second clinic was involved in the holistic management of this mother and her remaining child just as at the first clinic. With the aid of a Social worker another supervision order was completed while the mother was still deciding whether she should reinitiate ART and assess the HIV status of her remaining child.

\section{Discussion}

Unexpected transmission of HIV to the female, second-born, DZ twin was picked up in September 2014. At the time the guideline used for PMTCT was still Option B. The mother was on lifelong ART since 16 weeks pregnancy. The SA PMTCT Guidelines of April 2015 attempted to standardise ART initiation and prevent HIV resistance in mother-baby pairs. The overall goal is to decrease HIV transmission as efficiently as possible $[3,6,31]$. The decline in vertical transmission rate of HIV surpassed the targets set by the National Strategic Plan(NSP). MTCT at 6 weeks was reduced to a rate of $1,5 \%$ and $5 \%$ at 18 months in 2015 already. The NSP 2016 targets for vertical HIV transmission were set at a $2 \%$ rate at 6 weeks and $5 \%$ rate at 18 months respectively $[4,32]$.

\section{Mrs CM and Option B + PMTCT}

Monitoring of the HIV VL in pregnant women 3 months after initiation of ART is one of the changes implemented by the National Consolidated Guidelines for PMTCT since April 2015 [31-33]. The purpose of vigilant monitoring of the VL in pregnancy is to elicit an urgent response to detectable levels of circulating virus. Virological suppression equals PMTCT.

In our case study the mother's VL was not reassessed 3 months after the initiation of ART at her first ANC visit at 16 weeks gestation. Having not monitored the VL of the expectant mother at 3 monthly intervals might be seen in 2016 as a missed opportunity to PMTCT, promote adherence to lifelong ART and prevention of virological resistance. When the VL was eventually assessed at the 6 weeks postnatal visit it came to light that this mother was not virologically suppressed. Mrs CM was still breastfeeding at the time. If the VL was known to be . $>1000$ copies $/ \mathrm{ml}$ at 28 weeks, i.e., 3 months after initiation of ART, it was mandatory to repeat the VL after 1 month. The VL is expected to decrease with at least one $\log (10$ fold $)$ after the extra four weeks on treatment in a pregnant woman. To provide Pre exposure prophylaxis (PrEP) for the unborn baby the guidelines advise to switch the mother to second-line ART. Intensified adherence counselling follows automatically after any indication of a detectable viral load. Second line ART in itself is a challenge bacause of tablet load, dosage and side-effects, which is why counselling should be intensified before it even becomes necessary use Zidovudine, Lamividine and Lopinavir/ Ritonavir. PMTCT option B+ was unfortunately only effected in January 2015, too late for Mrs CM and her twins [4,6].

If the mother's VL is $>1000$ copies $/ \mathrm{ml}$ despite being on treatment longer than four weeks, infant prophylaxis need to be adjusted too. In our twin neonates Zidovudine could have been added to Nevirapine.
The duration, dose and type of prophylaxis given to the baby should be carefully documented in the Road to Health Booklet (RTHB). In April 2015 the updated PMTCT guideline stipulated that the lifelong HIV regimen started by the mother during or before pregnancy is to be recorded in the baby's RTHB as well. The results of birth PCR and choice of feeding practice also need to be noted. The page is perforated and may be removed when necessary for confidentiality. Documentation is crucial for continuation of follow-up management between facilities.

The PEP given to both twins was documented in each RTHB. On the other hand there was no documentation of the ART-regimen of the mother in any postnatal records from the hospital, the clinic or the RTHB. No record exists where and when she actually received her ART during breastfeeding. According to her own report she did not collect her ART when she picked up the Nevirapine of the twins, because she was receiving it from the gateway clinic at the hospital. The April guideline stresses that the mother-baby pairs have to collect their ART at the same visit. If scheduled with the monthly EPI visits it is expected to promote ART adherence because overall waiting times are shortened.

\section{Nearly $99 \%$ possibility of preventing vertical transmission of HIV from Mrs CM to her twins}

Early HIV testing during antenatal care is one of the interventions promoted by PMTCT. It is commendable that Mrs CM was initiated on ART without delay at her first antenatal visit. ART in pregnant women living with HIV, safer delivery techniques, exclusive breastfeeding in the first six months of life and uptake of infant testing are some of the interventions that made PMTCT programmes so successful in Southern Africa [4,6].

Management of the HIV-exposed infant starts with the mother's adherence to ART. Possible barriers to uptake of ART in this specific case might have been the initial high CD4 and that it gave a false sense security to mother and clinician alike. Apparently the stigma and perception of adverse effects with ART became stumbling blocks in the mother's ART adherence. The mother's referral to the high risk obstetric clinic denied her continuation in follow-up care by the dedicated health care worker she knew and trusted. The communication between the healthcare facilities failed Mrs CM as it was never noted who would be taking responsibility for her PMTCT ART.

The current guideline strongly encourages the initiation of neonatal ART at the primary health care facility. ${ }^{6}$ Were the HIV infected twin not referred to a Wellness clinic, she might have been initiated on ART in September 2014 instead of only January 2015.

\section{EID and Mrs CM's twin infants}

The EID program is the gold standard in paediatric HIV care since June 2015. The twin infants in the study were born in June 2014 and according to the ART guidelines of March 2013, targeted PCR testing was done at birth for high risk neonates only. No clinician, remembered that the twins were prematurely born at 35 weeks gestation and both weighed less than $2,5 \mathrm{~kg}$, which qualified them as high risk neonates. Their mother even received dexamethasone antenatally to improve the lung maturation of the babies. The obstetric indication for the caesarian section was noted as premature labour. Besides advocating highly sensitive polymerase chain reaction (PCR) testing for ALL HIV exposed infants, EID promotes linkage to immediate ART initiation for all neonates with a first positive PCR test. The PCR at birth aims 
to identify in utero infections, while the second PCR at 10 weeks is done to diagnose and treat peri-partum HIV transmission. Currently birth PCR results should be documented in the baby's records for all the HIV exposed neonates. Because mothers and babies are discharged within 6 hours after delivery the barcode of the PCR-test at birth should be pasted into the Road to Health Book. As soon as the referring facility becomes aware of a positive birth PCR result, it should be communicated to the mother and the receiving facility per telephone [6]. In the HIV Guidelines of January 2015 the PCR testing was standardised. All HIV-exposed babies need a PCR test at birth as soon as the baby is stable. By June 2015 Early Infant Diagnosis (EID) was attached as an addendum to the PMTCT program.

Both parents attended the first postnatal visit on day three of life. Thereafter the father never accompanied the mother voluntarily. When HIV transmission to the female baby was confirmed at six weeks, the parents went into denial. Especially the father could not understand how discordance in twins was possible. Emotions like sorrow and guilt are to be expected in the acceptance of the diagnosis. Sometimes denial is the only consolation. Counselling is a key component of the management plan of the highly emotive diagnosis of the HIV positive neonate or infant. Because parents are affected in various ways by the diagnosis of HIV transmission to a neonate it is often preferable that there is continuation of care by the same health care worker. The mother and father, or any other caregiver should be involved in the interpretation of results, implications of positive results and decisions about possible treatment plans. Parents must be convinced about the involvement of a team in the decision making with indeterminate or discordant results. That there would be diagnostic dilemmas should be communicated to the parents as well and documented as such. In the era of neonatal PEP and PrEP (post exposure and pre-exposure prophylaxis), it takes time to reach a conclusive diagnosis in the case of indeterminate test results and in this case discordant results. That research is ongoing to give answers to what we do not know about HIV needs to be brought out in the open. Honest communication about the duration of the diagnostic processes which might be long term is necessary. Unfortunately the father was difficult to locate and his doubts could never be addressed [34,35].

Every counsellor has the responsibility to convince the caregiver about the benefits of ART prophylaxis and therapy. Counselling is the responsibility of all the health care workers at the PHC. ART treatment plans need to be communicated verbally and also documented in the road to health booklet of the infant. It is critical for adherence that follow-up care is monitored carefully, to reassure the mother and/or guardians that there is ongoing follow-up and review by a designated health care worker who is part of a multi professional health care team. Treatment decisions are collaborated between the mother and the health care workers. Adherence during the breastfeeding period should be stressed by involving not only the mother but the rest of the family [32]. The mother is seen as the main agent to promote exclusive breastfeeding when she communicates her chosen feeding plan to her partner and household. If fathers and families are confused and uncertain in this scenario, the mother also will have a challenge with adherence and prognoses of the babies will be jeopardised. The caregivers of the twins seemed to have lost confidence and follow-up appointments were not kept. Meanwhile the infant were becoming immunologically compromised with an increasing viral load.

Meticulous up to date patient held records represents a drive to streamline communication between different health care providers and between the mother and the PHC. It is even a source of information for the extended family. In this case report existing patient records were used to track management plans, adherence and actual patient care over a period of two years. Even changes to the mother-twin pair's treatment plans in line with developing guidelines and outcomes could be followed-up. The information from the patient records serves as a source to review practices and improve on past mistakes. Every clinician knows the importance of accurate record keeping as it may prevent vertical HIV transmission in itself.

The question arises: Was it necessary to use legislative methods to retain the family in care? Although the male partner was involved in the first post natal visit, adherence suffered when he doubted the validity of the discordant HIV test results of the twins. In the January 2015 PMTCT guidelines it is specifically stated that if a mother is known to be HIV positive, ART prophylaxis may not be withheld from the infant. The healthcare provider has to ascertain that treatment in the best interest of the infant is administered to all HIV exposed children. All government employees must protect the rights of children as contained in the Children's Act $[35,36]$.

Providing care to the mother and baby pair affected by HIV is rapidly changing from month to month. HCW's are often not aware recent developments in HIV medicine i.e. the amended National HIV Paediatric testing guidelines. EID and PEP now include postpartum peri-exposure prophylaxis(PEEP) during the breastfeeding period [37]. These concepts are have not been internalised yet by HCW. So when confronted with a neonate with HIV the knowledge of previous guidelines often interferes with newer concepts. The further challenge of the PMTCT program in 2016 is to retain women on ART and achieve sustained virological suppression. Complete elimination of motherto-child transmission (MTCT) will be hard to accomplish. The first National Strategic Plan (NSP) was drawn up in 2003 and was hastily compiled [36]. In 2006, the cabinet signed off on the second NSP for HIV \& AIDS and STIs, The third NSP for 2007 - 2011, prepared by the South African National AIDS Council (SANAC) marked roll-out of ART by in South Africa. Since then the NSP has been re-formulated for the period of 2012 to 2016. The NDoH also revised the ARV guidelines in 2010. Some of the important decisions taken were the expansion of treatment to all children under one year and Option B+ PMTCT. Since 2012 at least 2 new versions of the ART guidelines were published per year [36]. The implication of this is that there is a need to standardise ART among all populations. Health care workers are often not aware of the minute details of the old version before a new version is published.

\section{Conclusion}

Challenge to clinicians: Are you well versed in the SA HIV Guidelines up to December 2016? The challenge in December 2016 is to culture adherence to ART in the quest for Elimination of HIV transmission from mother to child.

Challenge to scientists: Altering viral - host genetic immune reactions, the development of a vaccine or the study of elite controllers of HIV could provide some solutions in the search for a cure of HIV?

Meanwhile Mrs CM was found. She moved to live with her mother's on another farm in the district. She was reinitiated on ART on 11 October 2016. The remaining twin, who was 28 months old, had a rapid HIV test on the same day. The test ruled out the possibility of HIV infection in this boy.

\section{References}

1. Dinh TH, Delaney KP, Goga A, Jackson D, Lombard C, et al. (2015) Impact of maternal HIV seroconversion during pregnancy on early MTCT measured at 4-8 weeks post- 
partum in South Africa 2011-2012: A national population-based evaluation. PLOS One 10: e0125525. [Crossref]

2. Hoffman R, Black V, Technau K, Van der Merwe KJ, Currier J, et al. (2010) Effects of Highly Active Antiretroviral Therapy Duration and Regimen on Risk for Motherto-Child Transmission of HIV in Johannesburg, South Africa. J Acquir Immune Defic Syndr 54: 35-41. [Crossref]

3. Danel C, Moh R, Gabillard D, Badje A, Le Carrou1 J, et al. (2015) Early ART and IPT in HIV-infected African adults with high CD4 count (Temprano Trial). Conference on Retroviruses and Opportunistic Infections (CROI), Seattle, 23-26. [http://www. croiconference.org/abstract- guidelines\#abstract_submission] [Accessed 10.09.2016]

4. South Africa. Department of Health. National Consolidated Guidelines for PMTCT and the management of HIV in children, adolescents and children. April 2015. [https://www. health-e.org.za/2015/07/02/ guidelines-national-consolidated-guidelines-for-pmtct-andthe-management-of-hiv-in-children-adolescents- and-adults/] [Accessed: 8.11.2016]

5. McIntyre J (2016) HIV in pregnancy: a review. A 1998 working group on HIV in pregnancy by the Perinatal HIV Research Unit, University of Witwatersrand, Johannesburg, South Africa overseen by WHO and UNAIDS. [http://www.unaids.org/ sites/default/files/media_asset/jc151-hiv-in-pregnancy_en_1.pdf] [Accessed 30.10.2016]

6. South Africa. Department of Health. National consolidated guidelines for the prevention of mother-to-child transmission of HIV (PMTCT) and the management of HIV in children, adolescents and adults. Dec 2014. [https://gov.za-national guidelines consolidated mother to child transmission dec 2014]. [Accessed 14.10.2016]

7. Meintjes G, Black J, Conradie F, Cox V, Dlamini S, et al. (2014) Adult antiretroviral therapy guidelines 2014. By the Southern African HIV Clinicians Society. S Afr J HIV Med 15: 121-143.

8. Sherman GG (2015) HIV testing during the neonatal period. S Afr J HIV Med 16: 362. De Cock KM, Fowler MG, Mercier E, de Vincenzi I, Saba J, et al. (2000) Prevention of mother-to-child HIV transmission in resource-poor countries: translating research into policy and practice. JAMA 283: 1175-1182. [Crossref]

9. Teasdal CA, Marais BJ, Abrams EJ (2011) HIV: prevention of mother-to-child transmission. Systematic review 909. BMJ Clinical Evidence. BMJ Clin Evid 17: 0909. [http://clinicalevidence.bmj.com/x/systematic-review/0909/overview.html?ajax=true]. [Accessed 23.10.2016]

10. Mazenderani AF, Du Plessis NM, Thomas WN, Venter E, Avenant T (2014) Loss of detectability and indeterminate results: Challenges facing HIV infant diagnosis in South Africa's expanding ART programme. S Afr Med J 104: 574-577. [Crossref]

11. Haeri, M.A., Technau, K., Hsiao, N., Moritz, J., Carmona, S., Sherman, G. (2016) Recommendations for the management of indeterminate HIV PCR results within South Africa's early infant diagnosis programme. S Afr J HIV Med 17. [https://www. sajhivmed.org.za/index.php/hivmed/article/view/451/815. [Accessed: 23.10.2016].

12. Haeri Mazanderani AF, Du Plessis NM, Thomas WN, Venter E, Avenant T (2014) Loss of detectability and indeterminate results: Challenges facing HIV infant diagnosis in South Africa's expanding ART programme. S Afr Med J 104: 574-577. [crossref]

13. Hawkins D, Blott M, Clayden P, De Ruiter A, Foster G, et al. (2005) Guidelines for the management of HIV infection in pregnant women and the prevention of mother-tochild transmission of HIV. HIV Med 6: 107-148.

14. Cloete A (2013) Birth order, delivery and concordance of mother-to-child transmission of Human Immunodeficiency Virus in twin pregnancies. [Masters Thesis] Cape Town: University of Cape Town, Faculty of Health Sciences.

15. Duliège AM, Amos CI, Felton S, Biggar RJ, Goedert JJ (1995) Birth order, delivery route and concordance in transmission of Human Immunodeficiency Virus type 1 from mothers to twins. International Registry of HIV Exposed twins. J Pediatry 126: 625632. [Crossref]

16. Biggar RJ, Cassol S, Kumwenda N, Lema V, Janes M, et al. (2003) The risk of human immunodeficiency virus- 1 infection in twin pairs born to infected mothers in Africa. $J$ Infect Dis 188: 850-855. [Crossref]

17. Biggar RJ, Janes M, Pilon R, Roy R, Broadhead R, et al. (2002) Human immunodeficiency virus type 1 infection in twin pairs infected at birth. J Infect Dis 186: 281-285. [Crossref]

18. de Martino M, Tovo PA, Galli L, Caselli D, Gabiano C, et al. (1991) HIV-I infection in perinatally exposed siblings and twins. The Italian Register for HIV Infection in Children. Arch Dis Child 66: 1235-1238. [Crossref]

19. Menez-Bautista R, Fikrig SM, Pahwa S, Sarangadharan MG, Stoneburner RL (1986) Monozygotic twins discordant for the acquired immunodeficiency syndrome. Am J Dis Child 140: 678-679. [Crossref]
20. Young KK, Nelson RP, Good RA (1990) Discordant Human Immunodeficiency Virus infection in dizygotic twins detected by polymerase chain reaction. Pediatry Infect Dis J7: 454-456. [Crossref]

21. Park CL, Streicher H, Rothberg R (1987) Transmission of human immunodeficiency virus from parents to only one dizygotic twin. J Clin Microbiol 25: 1119-1121. [Crossref]

22. Goedert JJ (1997) Vertical transmission of Human Immunodeficiency Virus type 1: insights from studies of multiple pregnancies. Acta Paediatr Suppl 421: 56-59. [Crossref]

23. Scavalli CP, Mandelbrot L, Berrebi A, Batallan A, Cravello L, et al. (2007) Twin pregnancy as a risk factor for mother-to-child transmission of HIV-1: trends over 20 years. AIDS 21: 993-1002. [crossref]

24. Neubert J, Enczmann J, Krux F, Hower M, Borkhardt A, et al. (2010) Dizygotic twins discordant for HIV-1 despite vertical transmission prophylaxis: was human leukocyte antigen homozygosity of disadvantage to the infected twin? AIDS 24: 2295-2296. [Crossref]

25. Yang OO, Church J, Kitchen CM, Kilpatrick R, Ali A, et al. (2005) Genetic and stochastic influences on the interaction of Human Immunodeficiency Virus type 1 and Cytotoxic T Lymphocytes in identical Twins. J Virol 79: 15368-1537. [Crossref]

26. Biggar RJ, Taha TE, Hoover DR, Yellin F, Kumwenda N, et al. (2006) Higher in utero and perinatal HIV infection risk in girls than boys. J Acquir Immune Defic Syndr 41: 509-513. [Crossref]

27. Tazi L, Imamichi H, Hirschfeld S, Metcalf JA, Orsega S, et al. (2011) HIV-1 infected monozygotic twins: a tale of two outcomes. BMC Evol Biol 11: 62. [Crossref]

28. Morris L, Williamson C, Mngadi K (2016) Clinical trials and scientific discoveries give renewed hope for HIV vaccine. Spotlight 15: 118-119.

29. Nelson A, Maritz J, Giddy J, Nelson A, Maritz J, et al. (2015) HIV testing and antiretroviral therapy initiation at birth: Views from a primary care setting in Khayelitsha. S Afr J HIV Med 16: 376-380.

30. Peris K, Low M (2016) Are we meeting the NSP targets? Spotlight 15: 120-125.

31. Breastfeeding and HIV International Transmission Study Group, Coutsoudis A, Dabis F, Fawzi W, Gaillard P, et al. (2004) Late postnatal transmission of HIV-1 in breastfed children: an individual patient data meta-analysis. J Infect Dis 189: 2154-2166. [Crossref]

32. (2013) South Africa. Dept of Health. The South African Antiretroviral Treatmen Guidelines 2013. Revised PMTCT Guidelines. [http://www.kznhealth.gov.za/ medicine/2013_art_guidelines.pdf] [Accessed 14.10.2016]

33. Stinson K, Giddy J, Cox V, Burton R, Ibeto M, et al. (2014) Reflections on a decade of delivering.PMTCT in Khayelitsha, South Africa. 2014. S Afr J HIV Med 15: 30-32.

34. South Africa. Children's Act. No 38 of 2005.

35. Simelela NP, Venter WD (2014) A brief history of South Africa's response to AIDS. S Afr Med J 104: 249-251. [Crossref]

36. Kroon M (2015) Recognising and managing increased HIV transmission risk in newborns. S Afr J HIV Med 16: 371-378.

Copyright: (C2016 Lion-Cachet C. This is an open-access article distributed under the terms of the Creative Commons Attribution License, which permits unrestricted use, distribution, and reproduction in any medium, provided the original author and source are credited. 